\title{
High Performance PEFCs with Sputter-Deposited Pt Layer on Low-Pt-Loading Electrode
}

\author{
Shinichi HIRANO* and Futoshi FUJIKAWA
}

Received December 20, 1995 ; Accepted March 11, 1996

\begin{abstract}
A small amount of platinum (Pt) electrocatalyst $\left(0.05 \mathrm{mg} / \mathrm{cm}^{2}\right)$ was additionally deposited on the front surface of low-Pt-loading electrode $\left(20 \% \mathrm{Pt} / \mathrm{C}, 0.4 \mathrm{mg} / \mathrm{cm}^{2}\right)$, utilizing a sputtering deposition technique. The polymer electrolyte fuel cell (PEFC), utilizing this electrode for its cathode, showed an enhanced cell performance when using air at $0.15 \mathrm{MPa}$ as the oxidant gas. This enhancement in cell performance was attributed to improvement in the oxygen reduction reaction (ORR) kinetics, and lead to a $10 \%$ increase in its maximum power density, and to a $50 \mathrm{mV}$ cell voltage (corresponding to a $4 \%$ increase in LHV energy conversion efficiency) over almost the entire range of operational current densities.
\end{abstract}

\section{INTRODUCTION}

The polymer electrolyte fuel cell (PEFC) has been considered as one of the most promising candidates for a primary power source for an electric vehicle. However, higher power density and lower platinum (Pt) electrocatalyst loading on the electrodes, without any significant performance degradation, are still needed for such automotive application to become feasible.

To obtain higher power density, generally, larger amounts of $\mathrm{Pt}$ are loaded onto the electrodes; this would enhance electrochemical reaction kinetics. Thus, advanced PEFCs require large amounts of $\mathrm{Pt}$ loading electrodes $\left(4 \mathrm{mg} / \mathrm{cm}^{2}\right)^{1,2)}$. However, the high Pt electrocatalyst loading is unacceptable for automotive application because of its resultant high cost; thus, low Pt loading has become a constraint for the automotive application of PEFCs. Furthermore, in automotive application, the PEFC should be operated

Technical Research Center (Yokohama), Mazda Motor Corporation (2-5 Moriya-cho, Kanagawa-ku, Yokohama, Kanagawa 221, Japan)

Key Words: Electrode, Electrocatalyst, Sputtering Deposition, Voltage Increase with air as the oxidant gas, and at lower compression pressure because high air compression pressure imposes a penalty in energy consumption. However, for its part the low air compression pressure will be unfavorable for the kinetics of the electrochemical reaction, i.e. oxygen reduction reaction (ORR).

Therefore, much effort has been directed to reduce the $\mathrm{Pt}$ electrocatalyst loading, without an accompanying performance degradation. One of the most effective apprcaches for achieving low Pt loading while maintaining ORR kinetics is to improve $\mathrm{Pt}$ electrocatalyst utilization in the electrode. For that reason, smaller grain size ( 2 to $3 \mathrm{~nm}$ ) of Pt particles supported on carbon black particles have been used as the low-Pt-loading electrode ${ }^{3-13}$. Another approach is the localization of the Pt electrocatalyst at the reaction site, i.e. the front surface of the electrode, which has been pursued by sputter-depositing Pt on the front surface of the low-Pl-loading electrode ${ }^{13,14}$. According to studies addressing such techniques, the sputterdeposited Pt layer has proven to improve ORR kinetics ${ }^{13,14 \text {. }}$.

The use of the sputter-deposited Pt on the lowPt-loading electrode seems preferable for automotive application because of the benefits of higher ORR kinetics to compensate for the low compression pressure of air. In this study, the focus of the 
Table 1 Characteristics of MEAs used in the present study.

\begin{tabular}{lll} 
MEA\# & Anode & Cathode \\
\hline MEA 1 & $\mathrm{Pt} / \mathrm{C}$ & $\mathrm{Pt}(\mathrm{sp})+\mathrm{Pt} / \mathrm{C}$ \\
MEA 2 & $\mathrm{Pt}(\mathrm{sp})+\mathrm{Pt} / \mathrm{C}$ & $\mathrm{Pt}(\mathrm{sp})+\mathrm{Pt} / \mathrm{C}$ \\
MEA 3 & $\mathrm{Pt} / \mathrm{C}$ & $\mathrm{Pt} / \mathrm{C}$ \\
\hline
\end{tabular}

investigation was placed on the improvement of the PEFC electrode performance caused by the sputterdeposition of $\mathrm{Pt}$.

\section{EXPERIMENTAL}

\subsection{Preparation of Membrane and Electrodes Assemblies}

Three types of electrodes were examined for this investigation, (i) the sputter-deposited Pt on the front surface of low-Pt-loading electrode ( $\mathrm{Pt}(\mathrm{sp})+\mathrm{Pt}$ C), (ii) the low-Pt-loading electrode (Pt/C), and (iii) the sputter-deposited $\mathrm{Pt}$ on the uncatalyzed electrode (Pt(sp)). The Pt sputter-deposition was carried out in a low pressure argon environment $(2.7 \mathrm{~Pa})$. Sputtering conditions were $1.8 \mathrm{kV}$ acceleration voltage (RF), and $80 \mathrm{~mA}$ plate current. The deposition rate was $0.3 \mu \mathrm{g}$ $\mathrm{cm}^{2} / \mathrm{s}$. The amount of the sputter-deposited Pt on the electrodes was $0.05 \mathrm{mg} / \mathrm{cm}^{2}$. The $\mathrm{Pt} / \mathrm{C}$ and the uncatalyzed electrode were purchased from E-TEK, Inc., US. These electrodes have the same carbon cloth, amounts of carbon black loading $\left(4 \mathrm{mg} / \mathrm{cm}^{2}\right)$, and polytetrafluoroethylene (PTFE) content $(50 \mathrm{wt}$. \%). The thicknesses of these electrodes were $350 \mu \mathrm{m}$. The amount of $\mathrm{Pt}$ loading of the $\mathrm{Pt} / \mathrm{C}$ was $0.4 \mathrm{mg} / \mathrm{cm}^{2}$.

Three different membrane-and-electrodes assemblies (MEAs) are listed in Table 1. All MEAs used the Aciplex $-\mathrm{S} 1004$ perfluorinated sulfonic acid membrane supplied by the Asahi Chemical, Co. Ltd.; its equivalent weight was 1000 , and thickness was 100 $\mu \mathrm{m}$. All electrodes had an active geometric area of 10 $\mathrm{cm}^{2}$. The electrodes were impregnated with a Nafion ${ }^{\oplus}$ solution. The anode and cathode were hot pressed onto the membrane to form the MEAs. The amount of impregnated Nafion ${ }^{8}$ and the hot-press condition were as given in Ref. 15 .

\subsection{Cell Performance Evaluation and Cyclic Voltammetry}

The MEAs were positioned in a single-cell test fixture, and reversible hydrogen electrode (RHE) was installed on the anode side, as given in Ref. 3. The cell was installed in the test station, and the cell operating conditions (temperature, pressure, and gas flow rates) were set in the test station. In all cell performance evaluations, the cell was operated at a cell temperature of $80^{\circ} \mathrm{C}$, and under hydrogen and air, both at $0.15 \mathrm{MPa}$. The reactant gases were humidified via bubbling through hot water $\left(85^{\circ} \mathrm{C}\right)$. The reactant gas flow rates were always at least three times as much as the stoichiometric levels. The electric power from the cell was connected to an electronic load box (Kikusui, Model PLZ152WA), which interfaced with a personal computer to control the current density.

Cyclic voltammetry (CV) was carried out to estimate the electrochemically active surface areas of the electrodes. $\mathrm{CV}$ was performed by a potentiostat (Hokuto-Denko, HA-520G), and the potential range and the sweep rate were $0.1 \mathrm{~V}$ to $1.1 \mathrm{~V}$ vs. RHE and 50 $\mathrm{mV} / \mathrm{s}$, respectively. The electrochemically active surface area was obtained from the charge required for hydrogen desorption from the Pt electrocatalyst. For the calculation of the roughness factor, the total charge of hydrogen desorption was assumed to be $210 \mu \mathrm{C}$ $\mathrm{cm}^{2}$ on a smooth Pt surface.

\subsection{Morphological Characterization}

The dry MEAs were cut and their cross-sections

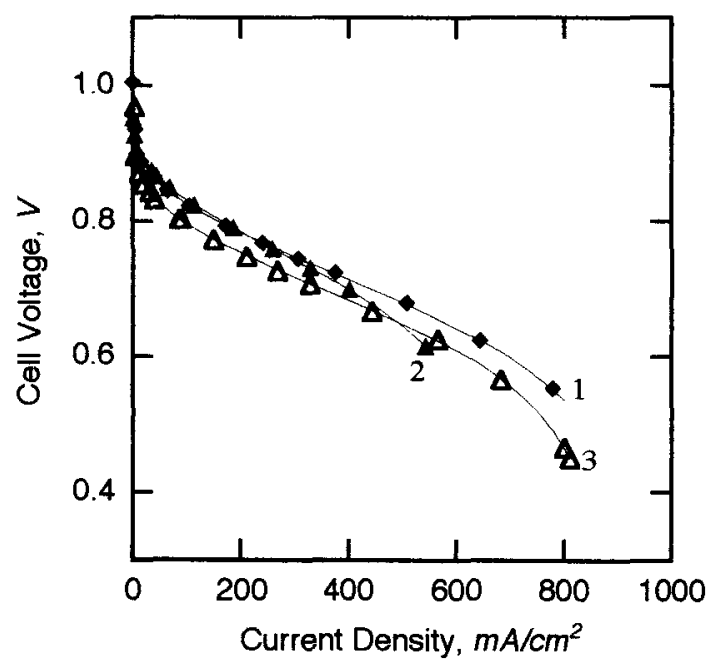

Fig. 1 Cell voltage vs. current density plots in PEFCs at $80^{\circ} \mathrm{C}, \mathrm{H}_{2} / \mathrm{Air}, 0.15 \mathrm{MPa} \bullet \mathrm{MEA} 1, \triangle \mathrm{MEA} 2, \triangle$ MEA 3. 
Table 2 Comparison of cell parameters, at $80^{\circ} \mathrm{C}$, with $\mathrm{H}_{2} / \mathrm{Air}$ gas stream, at $0.15 \mathrm{MPa}$.

\begin{tabular}{lccccc}
\hline MEA\# & $\begin{array}{c}E_{0} \\
(\mathrm{mV})\end{array}$ & $\begin{array}{c}b \\
(\mathrm{mV} / \text { dec. })\end{array}$ & $\begin{array}{c}R \\
\left(\Omega \mathrm{cm}^{2}\right)\end{array}$ & $\begin{array}{c}\text { Anode Voltage vs. RHE (mV) } \\
\left(100 \mathrm{~mA} / \mathrm{cm}^{2}\right.\end{array} \quad 300 \mathrm{~mA} / \mathrm{cm}^{2}$ \\
\hline MEA 1. & 956 & 52 & 0.26 & 9 & 13 \\
MEA 2 & 947 & 41 & 0.34 & 12 & 23 \\
MEA 3 & 936 & 57 & 0.27 & 7 & 18 \\
\hline
\end{tabular}

were exposed. Electron probe micro-analysis (EPMA) was conducted to analyze the Pt localization in the cross-sections of MEAs. The EPMA data were recorded in wavelength dispersive mode. Scanning electron microscopy (SEM) was used to examine the surface morphology of the sputter-deposited Pt layer.

\section{RESULTS AND DISCUSSION}

\subsection{ORR Kinetics and Mass Transport Problem with}

\section{Sputter-Deposited Pt Layer}

Figure 1 shows plots of the cell voltage vs. current density for single cells of MEAs 1 to 3 . The electrode kinetics, ohmic parameters, and anode overpotentials of these MEAs are tabulated in Table 2. These kinetics and ohmic parameters were analyzed by Equation (1), utilizing the data up to the end of the linear region of the cell potential versus current density,

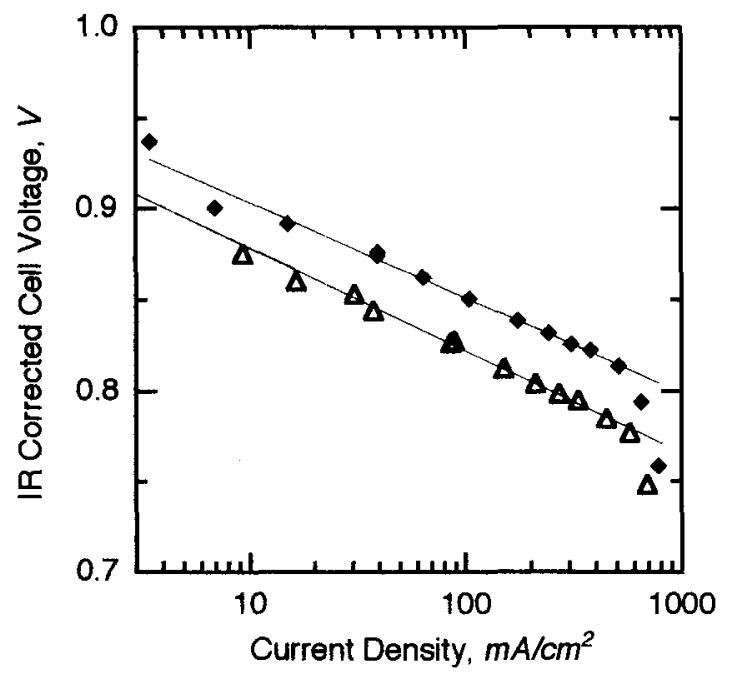

Fig. 2 IR-corrected cell voltage vs. current density Tafel plots in PEFCs at $80^{\circ} \mathrm{C}$; MEA 1, $\triangle \mathrm{MEA} 3$. as applied and shown in Ref. 3 .

$$
E=E_{0}-b \log i-i R
$$

It is assumed in Equation (1) that mass transport limitations and activation overpotential at the anode are negligible as compared with those at the cathode. The Tafel slope is represented by $b$, and $R$ represents the resistance which causes a linear variation of the potential with current density. Using the values and the experimental cell voltage $E$, the IR-corrected Tafel plots were prepared by plotting $E+i R$ against $\log i$.

According to Fig. 1, the cell voltages of MEA 1 are always higher than those of MEA 3 over the entire operating current density region. The cell voltage of MEA 2, indicates almost the same cell voltage as in MEA 1 at current densities lower than $260 \mathrm{~mA} / \mathrm{cm}^{2}$. Figure 2 shows the IR-corrected Tafel plots of MEAs 1 and 3. Since the anode voltages vs. RHE of MEAs 1

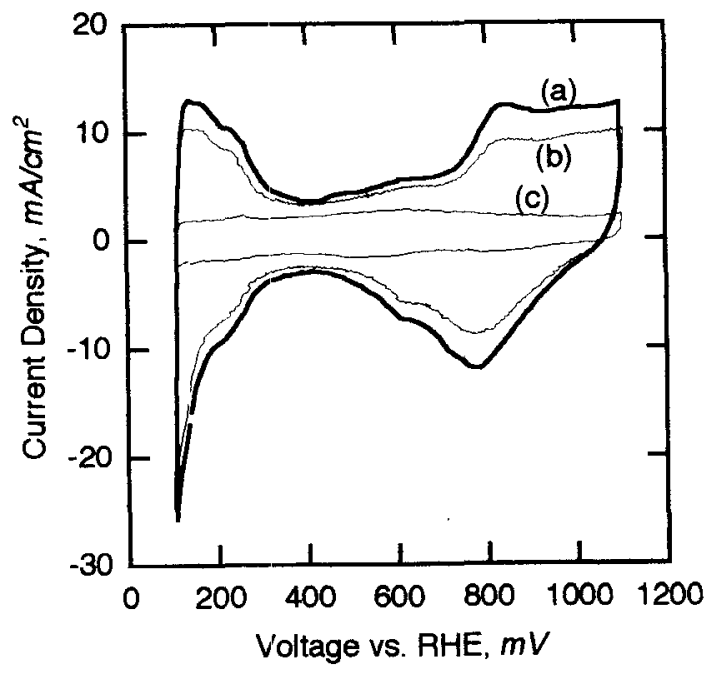

Fig. 3 Cyclic voltammograms at $60^{\circ} \mathrm{C}$ for electrodes; (a) $\mathrm{Pt}$ (sp)+Pt/C, (b) Pt/C, (c) Pt(sp). 
Table 3 Roughness factors and anount of Pt loadings of electrodes.

\begin{tabular}{lcr}
\hline Electrode & $\begin{array}{c}\text { Amount of Pt Loading } \\
\left(\mathrm{mg} / \mathrm{cm}^{2}\right)\end{array}$ & Roughness Factor \\
\hline $\mathrm{Pt}(\mathrm{sp})+\mathrm{Pt} / \mathrm{C}$ & 0.45 & 165 \\
$\mathrm{Pt} / \mathrm{C}$ & 0.4 & 113 \\
$\mathrm{Pt}(\mathrm{sp})$ & 0.05 & 8 \\
\hline
\end{tabular}

to 3 are all low at $100 \mathrm{~mA} / \mathrm{cm}^{2}$ (Table 2), the cell voltages are considered to exhibit the cathode voltages vs. RHE in the activation control region. The high cell performance of MEA 1 compared with that of MEA 3 is ascribed to the improvement of ORR kinetics by the sputter-deposited Pt layers (Fig. 2: and Table 2).

Figure 3 shows the cyclic voltammograms for the three types of electrodes: $\mathrm{Pt}(\mathrm{sp})+\mathrm{Pt} / \mathrm{C}, \mathrm{Pt} / \mathrm{C}$, and $\mathrm{Pt}(\mathrm{sp})$. The roughness factors and the amounts of $\mathrm{Pt}$ loading have been tabulated in Table 3 . The roughness factor of $\mathrm{Pt}(\mathrm{sp})+\mathrm{Pt} / \mathrm{C}$ was 1.5 times as large as that of $\mathrm{Pt} / \mathrm{C}$, although the amount of Pt loading was only 1.1 times. The difference in the roughness factors between the two electrodes was 52 - entirely attributable to the contribution of the sputter-deposited Pt layer of $\mathrm{Pt}(\mathrm{sp})+\mathrm{Pt} / \mathrm{C}$. Otherwise, the roughness factor of $\mathrm{Pt}(\mathrm{sp})$ was 8. Since the amounts of carbon black and PTFE content were the same across these three electrodes, it can be assumed that the gas diffusion characteristics and ohmic resistances in the electrodes also have the same magnitudes. Thus, the difference in the roughness factors of the sputter-deposited $\mathrm{Pt}$ between $\mathrm{Pt}(\mathrm{sp})+\mathrm{Pt} /$ $\mathrm{C}$ and $\mathrm{Pt}(\mathrm{sp})$ was assumed to be the result of the difference in the utilization of Pt electrocatalyst and/or in the cluster sizes of the sputter-deposited Pt.

According to Fig. 1, at current densities higher than $260 \mathrm{~mA} / \mathrm{cm}^{2}$, the cell voltage of MEA 2 departs from linearity and begins to drop. MEA 2 shows higher mass transport type overpotential than MEAs 1 and 3 .

\subsection{Cell Performance Improvement}

Comparison of the cell performances among MEAs 1 to 3 are listed in Table 4. The maximum power density of MEA 1 is 1.1 times as large as that of MEA 3. The cell voltage plot of MEA 1, along with its current density, parallels that of MEA 3 (Fig. 1), and
Table 4 Comparison of cell performances.

\begin{tabular}{|c|c|c|}
\hline MEA\# & $\begin{array}{l}\text { Max. Power Density } \\
\qquad\left(\mathrm{W} / \mathrm{cm}^{2}\right)\end{array}$ & $\begin{array}{r}\text { Energy Conversion } \\
\text { Efficiency (LHV) } \\
\left(\% @ 500 \mathrm{~mA} / \mathrm{cm}^{2}\right)\end{array}$ \\
\hline MEA 1 & $0.43\left(@ 780 \mathrm{~mA} / \mathrm{cm}^{2}\right)$ & 56 \\
\hline MEA 2 & $0.33\left(@ 542 \mathrm{~mA} / \mathrm{cm}^{2}\right)$ & 52 \\
\hline MEA 3 & $0.39\left(@ 720 \mathrm{~mA} / \mathrm{cm}^{2}\right)$ & 52 \\
\hline
\end{tabular}

the cell voltage of MEA 1 is $50 \mathrm{mV}$ higher than that of MEA 3 at the current density of $500 \mathrm{~mA} / \mathrm{cm}^{2}$. It can be deduced, then, that the energy conversion efficiency has increased $4 \%$ for the low heating value (LHV). In MEA 1, the ORR kinetic improvement, together with the lower mass transport type problem, have resulted in good cell performance.

\subsection{Electrode Microstructure and Surface Morphology}

$\mathrm{Pt}$ concentration line profiles of MEA crosssections measured by EPMA for MEAs 2 and 3 are shown in Fig. 4. For MEA 2, the prominent Pt intensity in the immediate vicinity of the electrode and membrane interface was caused by the sputter-deposited Pt layer. The catalyzed layer of cathode consists of a $40 \mu \mathrm{m}$ layer of the low-Pt- loading and a thin $(3 \mu \mathrm{m})$ layer of high $\mathrm{Pt}$ content. It was considered that this feature caused the better utilization of Pt electrocatalyst as mentioned in Table 3. Figure 5 shows the SEM images of the electrode surface for $\mathrm{Pt}(\mathrm{sp})+\mathrm{Pt} / \mathrm{C}$ and $\mathrm{Pt} / \mathrm{C}$. Since these two images were obtained with the same acceleration voltage $(20 \mathrm{kV})$, and the sample currents of these images were almost the same $(10 \mu \mathrm{A})$, clear and bright images of $\mathrm{Pt}(\mathrm{sp})+\mathrm{Pt} / \mathrm{C}$ are the result of the presence of sputter-deposited Pt layer. This feature verifies, then, that the sputter-deposited Pt layer covers the surface of the electrodes. At the current density of $300 \mathrm{~mA} / \mathrm{cm}^{2}$, the anode voltage vs. RHE of MEA 2 is higher than those of MEAs 1 and 3 (Table 2). It is assumed that hindered water transportation through the sputtered layer in the anode caused lower proton conductivity in the membrane, and also caused higher transport type overpotential of MEA 2 as mentioned in Section 3.1.

\section{CONCLUSION}




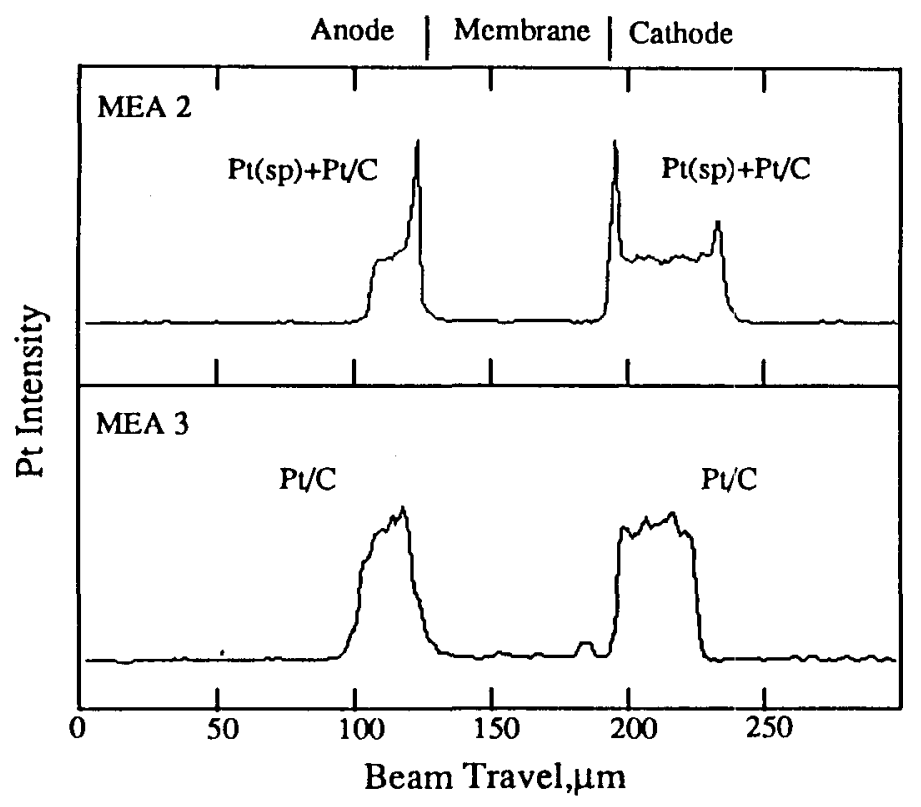

Fig. 4 Pt concentration line profiles of the MEAs cross-section measured by EPMA.

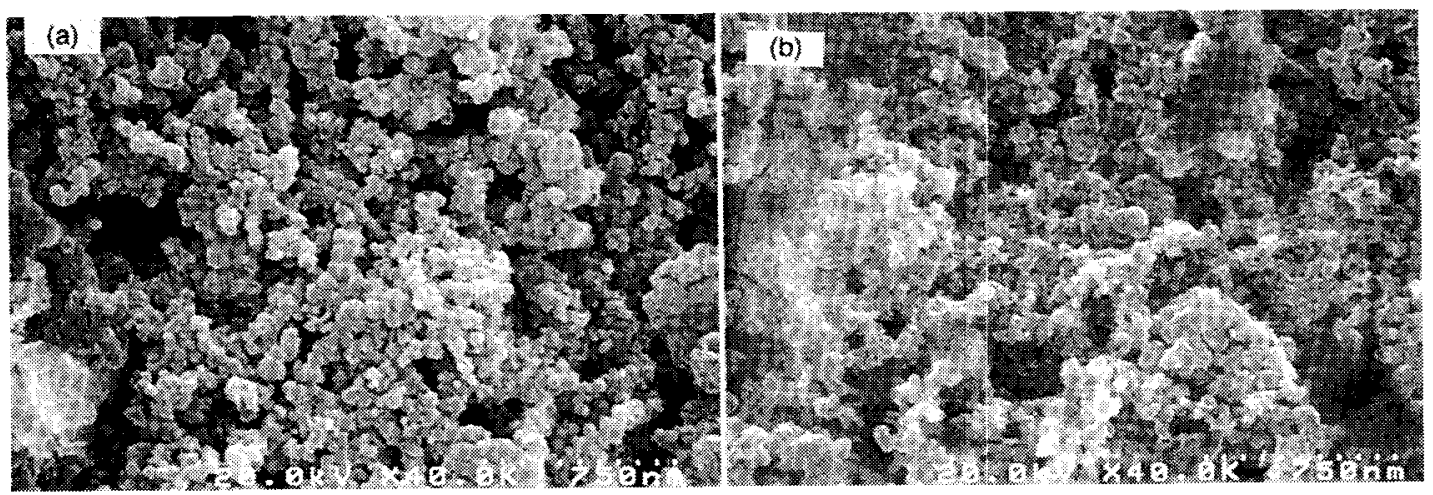

Fig. 5 SEM images of the electrode surface; (a) $\mathrm{Pt}(\mathrm{sp})+\mathrm{Pt} / \mathrm{C}$, (b) $\mathrm{Pt} / \mathrm{C}$.

Through this work, it was observed the cell performance was enhanced in the PEFC with the use of the sputter-deposited Pt layer on the low-Pt-loading electrode for the cathode, and using air as the reactant gas at a pressure of $0.15 \mathrm{MPa}$. This feature would be beneficial for automotive applications, where the PEFC should be operated in air at low compression pressure. The estimated cell performance was improved by 10 $\%$ in the maximum power density, and there was a $4 \%$ elevation in the L.HV energy conversion efficiency, when compared to the PEFC with low-Pt-loading electrodes for both the anode and the cathode. This cell performance improvement was the result of the improvement in ORR kinetics and the lower mass transport type overpotential when sputter-deposited Pt layer was applied to the cathode but not to the anode. Further investigations are needed to verify the assumption of hindered water transportation in the 
sputter-deposited Pt layer.

This work was carried out under the financial support from the Agency of Industrial Science and Technology - the Ministry of International Trade and Industry.

\section{references}

1) K. B. Prater, J. Power Sources, 29, 239 (1990).

2) R. Mosdale and S. Srinivasan, Electrochimi. Acta, 40, 413 (1995).

3) E. A. Ticianelli, C. R. Derouin, A. Redondo and S. Srinivasan, J. Electctrochem. Soc., 185, 2209 (1988).

4) E. A. Ticianelli, C. R. Derouin and S. Srinivasan, $J$. Electroanal. Chem., 251, 275 (1988).

5) S. Srinivasan, E. A. Ticianelli, C. R. Derouin and A. Redondo, J. Power Sources, 22, 359 (1992).

6) E. Taylor, E. Anderson and N. Vilambi, $J$. Electrochem. Soc., 139, LA5 (1992).

7) M. Wilson and S. Gottesfeld, J. Electrochem. Soc., 139, L,28 (1992).

8) M. W. Verbrugge, J. Electrochem. Soc., 141, 46 (1992).

9) S. Srinivasan, A. C. Ferreira, A. Parthasarathy, O. A. Velev, and A. J. Appleby, Methods to Attain High
Energy Efficiencies and Long Lifetimes in Polymer Acid Fuel Cells, Annual Report, Grant No. NAG31125, NASA-Lewis Research Center, Cleveland $\mathrm{OH},(1992)$.

10) S. Swathirajan, Y. M. Mikhail, Ext. Abs., 185th Meeting Electrochem. Soc., San Francisco, CA, May 1994, The Electrochemical Society, Pennington, NJ, p. 967, (1994).

11) M. Mizuhata, K. Yasuda, K. Oguro and $\mathrm{H}$ Takenaka, Proc. 1st Int'l Symposium on Proton Exchange Membrane Fuel Cells I, Chicago, IL,Oct. 1995, The Electrochemical Society, Pennington, NJ, PV95-23, p.24, (1994).

12) S. Srinivasan, D.J. Manko, H, Koch, M.A. Enayetullah and A.J. Appleby, J. Power Sources, 29, 367 (1990).

13) S. Srinivasan, O. A. Velev, A. Parthasarathy, D. J. Manko and A. J. Appleby, J. Power Sources, 36, 299 (1991).

14) S. Mukerjee, S. Srinivasan and A.J. Appleby, Electrochem. Acta, 38, 1661 (1993).

15) A. C. Ferreira, S. Srinivasan and A. J. Appleby, Proc. Symposium on Batteries and fuel cells for stationary and electric vehicle applications, Hawaii, May 1993, The Electrochemical Society, Pennington, NJ , PV93-8, p.282, (1993). 